\title{
Azospirillum zeae sp. nov., a diazotrophic bacterium isolated from rhizosphere soil of Zea mays
}

Correspondence

George Lazarovits

lazarovitsg@agr.gc.ca

\author{
Samina Mehnaz, ${ }^{1,2}$ Brian Weselowski ${ }^{2}$ and George Lazarovits ${ }^{2}$ \\ ${ }^{1}$ School of Biological Sciences, Quaid-e-Azam Campus, University of the Punjab, Lahore 54590, \\ Pakistan \\ ${ }^{2}$ Southern Crop Protection and Food Research Centre, Agriculture and Agri-Food Canada, \\ 1391 Sandford Street, London, ON N5V 4T3, Canada
}

Two free-living nitrogen-fixing bacterial strains, $\mathrm{N} 6$ and $\mathrm{N7}^{\top}$, were isolated from corn rhizosphere. A polyphasic taxonomic approach, including morphological characterization, Biolog analysis, DNA-DNA hybridization, and $16 \mathrm{~S}$ rRNA, cpn60 and nifH gene sequence analysis, was taken to analyse the two strains. $16 \mathrm{~S}$ rRNA gene sequence analysis indicated that strains $\mathrm{N} 6$ and $N 7^{\top}$ both belonged to the genus Azospirillum and were closely related to Azospirillum oryzae (98.7 and $98.8 \%$ similarity, respectively) and Azospirillum lipoferum (97.5 and $97.6 \%$ similarity, respectively). DNA-DNA hybridization of strains $\mathrm{N} 6$ and $N 7^{\top}$ showed reassociation values of 48 and $37 \%$, respectively, with $A$. oryzae and $43 \%$ with $A$. lipoferum. Sequences of the $n i f H$ and cpn60 genes of both strains showed 99 and $\sim 95 \%$ similarity, respectively, with those of $A$. oryzae. Chemotaxonomic characteristics (Q-10 as quinone system, 18:1 $17 \mathrm{c}$ as major fatty acid) and $\mathrm{G}+\mathrm{C}$ content of the DNA (67.6 mol\%) were also similar to those of members of the genus Azospirillum. Gene sequences and Biolog and fatty acid analysis showed that strains N6 and $\mathrm{N} 7^{\top}$ differed from the closely related species $A$. lipoferum and $A$. oryzae. On the basis of these results, it is proposed that these nitrogen-fixing strains represent a novel species. The name Azospirillum zeae sp. nov. is suggested, with $N 7^{\top}\left(=\right.$ NCCB $100147^{\top}=$ LMG $\left.23989^{\top}\right)$ as the type strain.
Diverse nitrogen-fixing bacteria have been isolated from the roots of numerous wild and cultivated grasses grown in tropical, subtropical and temperate regions all over the world. Among these bacteria, Azospirillum spp. have been isolated from various geographical regions of the world. Members of this genus are known to be associated with roots of numerous wild and cultivated grasses, cereals, food crops and soils in various regions (Peng et al., 2006). The genus Azospirillum was first described by Tarrand et al. (1978) and comprised two species: Azospirillum lipoferum and Azospirillum brasilense. The genus currently comprises 10 species, including Azospirillum amazonense (Magalhães et al., 1983), Azospirillum halopraeferens (Reinhold et al., 1987), Azospirillum irakense (Khammas et al., 1989), Azospirillum largimobile (Ben Dekhil et al., 1997), Azospirillum doebereinerae (Eckert et al., 2001), Azospirillum oryzae (Xie \& Yokota, 2005), Azospirillum melinis (Peng et al., 2006)

Abbreviation: IAA, indole acetic acid.

The GenBank/EMBL/DDBJ accession numbers for the 16S rRNA, cpn60 and nifH gene sequences of strain N6 are DQ682469, DQ682474 and DQ682471, respectively; the corresponding accession numbers for strain N7 ${ }^{\top}$ are DQ682470, DQ682473 and DQ682472. and Azospirillum canadense (Mehnaz et al., 2007). In studies aimed at identifying the bacterial rhizosphere

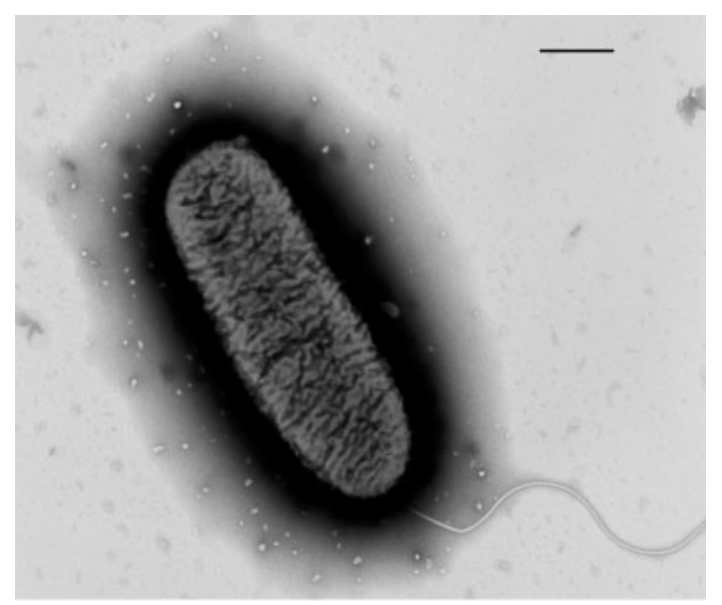

Fig. 1. Electron micrograph showing cell morphology of corn isolate N6. Bar, $0.6 \mu \mathrm{m}$. 
Table 1. Physiological differences between Azospirillum zeae sp. nov. isolates $\mathrm{N} 6$ and $N 7^{\top}$ and other Azospirillum species

Taxa: 1, A. zeae $\mathrm{N7}^{\mathrm{T}}$ and N6; 2, A. oryzae IAM $15130^{\mathrm{T}} ; 3$, A. lipoferum ATCC $29707^{\mathrm{T}} ; 4$, A. melinis TMCY $0552^{\mathrm{T}}$; 5, A. doebereinerae. +, Positive; -, negative; v, variable; ND, not determined. Data for carbon source utilization by A. oryzae, A. lipoferum and A. melinis are from Mehnaz et al. (2007); data for N6, N7 $7^{\mathrm{T}}$ and $A$. doebereinerae are from this study. Other data for A. oryzae, A. lipoferum, A. melinis and A. doebereinerae are taken from Eckert et al. (2001), Peng et al. (2006) and Xie \& Yokota (2005).

\begin{tabular}{|c|c|c|c|c|c|}
\hline Characteristic & 1 & 2 & 3 & 4 & $5^{*}$ \\
\hline Motility & + & + & + & - & + \\
\hline Biotin requirement & - & + & + & - & - \\
\hline Growth with $2 \% \mathrm{NaCl}$ & - & - & - & + & - \\
\hline Growth at $41{ }^{\circ} \mathrm{C}$ & + & - & - & - & - \\
\hline Optimum growth temperature $\left({ }^{\circ} \mathrm{C}\right)$ & 30 & 30 & 37 & $20-33$ & 30 \\
\hline $\mathrm{pH}$ range for growth & $5.0-7.0$ & $6.0-7.0$ & $6.0-7.0$ & $4.0-8.0$ & $6.0-7.0$ \\
\hline Gelatin hydrolysis & - & + & + & ND & - \\
\hline \multicolumn{6}{|l|}{ Carbon source utilization: } \\
\hline$N$-Acetyl-D-glucosamine & $\mathrm{V}$ & - & + & + & - \\
\hline L-Arabinose & + & + & + & + & + \\
\hline D-Cellobiose & - & - & - & - & - \\
\hline D-Fructose & + & + & + & + & + \\
\hline L-Fucose & + & - & + & + & - \\
\hline D-Galactose & + & + & + & + & + \\
\hline Gentiobiose & - & - & - & - & - \\
\hline D-Glucose & $\mathrm{V}$ & + & + & + & + \\
\hline Glycerol & + & + & + & + & + \\
\hline myo-Inositol & - & - & + & - & - \\
\hline Lactose & - & - & - & - & - \\
\hline Maltose & - & - & - & + & - \\
\hline D-Mannitol & + & - & + & + & + \\
\hline D-Mannose & - & - & + & - & - \\
\hline L-Rhamnose & - & - & - & - & - \\
\hline D-Sorbitol & + & - & - & + & + \\
\hline Sucrose & - & - & - & - & - \\
\hline Trehalose & - & - & - & - & - \\
\hline DNA G $+\mathrm{C}$ content $(\mathrm{mol} \%)$ & 67.6 & 66.8 & $69-70$ & 68.7 & 70.7 \\
\hline
\end{tabular}

${ }^{\star}$ DNA G $+\mathrm{C}$ content and carbon source utilization data are for A. doebereinerae GSF71 ${ }^{\mathrm{T}}$; all other data refer to more than one strain.

residents of corn plants grown in Southern Ontario, Canada, several bacterial strains were isolated from soil adhering to corn roots. Some of them were found to fix nitrogen and form pink dry colonies on malate medium. These bacteria were compared with Azospirillum spp. by using microbial and molecular biology techniques. Previously, on the basis of partial 16S rRNA gene sequencing, isolate $\mathrm{N}^{\mathrm{T}}$ was identified and reported as $A$. lipoferum (Mehnaz \& Lazarovits, 2006). In this study, this isolate has been re-identified and isolation and identification of another Azospirillum strain, N6, from corn rhizosphere using a polyphasic approach is reported.

Isolates $\mathrm{N} 6$ and $\mathrm{N}^{\mathrm{T}}$ were isolated on $\mathrm{M}$ medium (Xie \&Yokota, 2005) except that biotin was not added and the medium was $\mathrm{pH}$ 7.2-7.4. Subcultivation was done on the same medium at $30{ }^{\circ} \mathrm{C}$ for $48-72 \mathrm{~h}$. The isolates formed flat pink colonies on $\mathrm{M}$ medium. With time, these colonies became dried and wrinkled. Cell morphology was observed by transmission electron microscopy (Zeiss EM902). Cell morphology of $\mathrm{N} 6$ and $\mathrm{N}^{\mathrm{T}}$ was similar. Both strains showed a single polar flagellum in liquid medium, although $\mathrm{N}^{\mathrm{T}}$ cells were bigger than those of N6; cells of N6 were $0.9-1.1 \times 1.9-3.3 \mu \mathrm{m}$ (Fig. 1) and those of $\mathrm{N}^{\mathrm{T}}$ were $1.5 \times 3.4-6.8 \mu \mathrm{m}$. Bacterial growth at different temperatures $\left(20-41{ }^{\circ} \mathrm{C}\right), \mathrm{pH}$ values $(4-10)$ and various $\mathrm{NaCl}$ concentrations $(0.5-3.0 \%)$ was determined on $\mathrm{M}$ medium. The Biolog analysis system and API 20NE bacterial identification kit were used for physiological characterization. Results of the analyses are given in the species description. A summary of the results, including carbon source utilization tests, suitable for the differentiation of isolates $\mathrm{N} 6$ and $\mathrm{N}^{\mathrm{T}}$ from known Azospirillum species is presented in Table 1 . In Table $1, \mathrm{~N} 6, \mathrm{~N}^{\mathrm{T}}$ and $A$. 
Table 2. Cellular fatty acid composition of corn rhizosphere isolates N6 and $\mathrm{N}^{\top}$ and closely related Azospirillum species

Strains: $1, \mathrm{~N} 6 ; 2, \mathrm{~N}^{\mathrm{T}} ; 3$, A. oryzae IAM $15130^{\mathrm{T}}$ (data from Mehnaz et al., 2007); 4, A. lipoferum ATCC $29707^{\mathrm{T}}$ (data from Mehnaz et al., 2007). Fatty acid values are given as percentages of the total peak area. ND, Not detected.

\begin{tabular}{|lrrrr|}
\hline Fatty acid & $\mathbf{1}$ & $\mathbf{2}$ & $\mathbf{3}$ & $\mathbf{4}$ \\
\hline $13: 1$ at $12-13$ & $\mathrm{ND}$ & 0.34 & 0.6 & 0.7 \\
$14: 0$ & 0.7 & 0.6 & 0.5 & 0.7 \\
$15: 0$ & 0.7 & 0.8 & 0.5 & 1.4 \\
$16: 0$ & 5.6 & 5.6 & 6.9 & 4.3 \\
$17: 0$ & 0.4 & 0.5 & 0.3 & 0.8 \\
$18: 0$ & 0.8 & 0.4 & 0.7 & 0.5 \\
$15: 03-\mathrm{OH}$ & 0.3 & 0.4 & $\mathrm{ND}$ & 0.8 \\
$16: 03-\mathrm{OH}$ & 4.3 & 4.2 & 4.1 & 4.3 \\
$17: 03-\mathrm{OH}$ & $\mathrm{ND}$ & 0.3 & $\mathrm{ND}$ & 0.6 \\
$18: 03-\mathrm{OH}$ & 0.6 & 0.4 & 0.5 & 0.5 \\
$18: 12-\mathrm{OH}$ & 6.3 & 5.7 & 5.0 & 5.5 \\
$15: 1 \omega 8 c$ & 0.3 & 0.4 & $\mathrm{ND}$ & 0.6 \\
$17: 1 \omega 8 c$ & 1.9 & 2.1 & 0.8 & 3.4 \\
$17: 1 \omega 6 c$ & 3.2 & 3.7 & 1.4 & 7.1 \\
$18: 1 \omega 7 c$ & 54.4 & 54.9 & 57.2 & 53.4 \\
$19: 0$ cyclo $\omega 8 c$ & $\mathrm{ND}$ & $\mathrm{ND}$ & 0.8 & 1.6 \\
Summed feature $2^{*}$ & 5.6 & 5.5 & 5.3 & 5.9 \\
Summed feature $3 *$ & 14.4 & 13.9 & 14.6 & 6.5 \\
\hline
\end{tabular}

${ }^{*}$ Summed features: summed feature 2, 12:0 aldehyde (unknown), $16: 1$ iso I/14:0 3-OH; summed feature 3, 16:1 $1 \omega 7 c / 16: 1 \omega 6 c$. melinis showed the same pattern for carbon source utilization, but there are 28 carbon sources that can be used by A. melinis, but not by $\mathrm{N} 6$ and $\mathrm{N}^{\mathrm{T}}$ (data not shown). Phosphate solubilization on NBRIP medium (Nautiyal, 1999) was not observed. Indole acetic acid (IAA) production in the presence of $100 \mathrm{mg}$ tryptophan $1^{-1}$ in CCM (Rennie, 1981) was quantified by HPLC as described by Mehnaz et al. (2001). The amount of IAA produced by both strains was $6.0-6.5 \mu \mathrm{g} \mathrm{ml}^{-1}$.

Cellular fatty acid profiles of isolates $\mathrm{N} 6$ and $\mathrm{N}^{\mathrm{T}}$ were determined by GC using the Sherlock Microbial Identification system (MIDI) according to a standard protocol (Paisley, 1996); data are shown in Table 2.

Determination of DNA base composition was carried out using the HPLC technique described by Mesbah et al. (1989). The DNA G+C content of strain $\mathrm{N}^{\mathrm{T}}$ was $67.6 \mathrm{~mol} \%$, which is in accordance with the values given for members of the genus Azospirillum (64-71 mol\%; Ben Dekhil et al., 1997). The 16S rRNA genes of $\mathrm{N} 6$ and $\mathrm{N}^{\mathrm{T}}$ were amplified using the primers (FGPS4-281 bis, AGAGTTTGATCCTGGCTCAG; FGPS1509-153, AAGGAGGTGATCCAGCCGCA; Normand, 1995) and PCR conditions described by Mehnaz et al. (2001). PCR products of $1.5 \mathrm{~kb}$ were obtained. Phylogenetic analysis was performed using the software package BIONUMERICS (Applied Maths, Belgium) after including the consensus sequence in an alignment of small ribosomal subunit sequences collected from EMBL. The alignment was

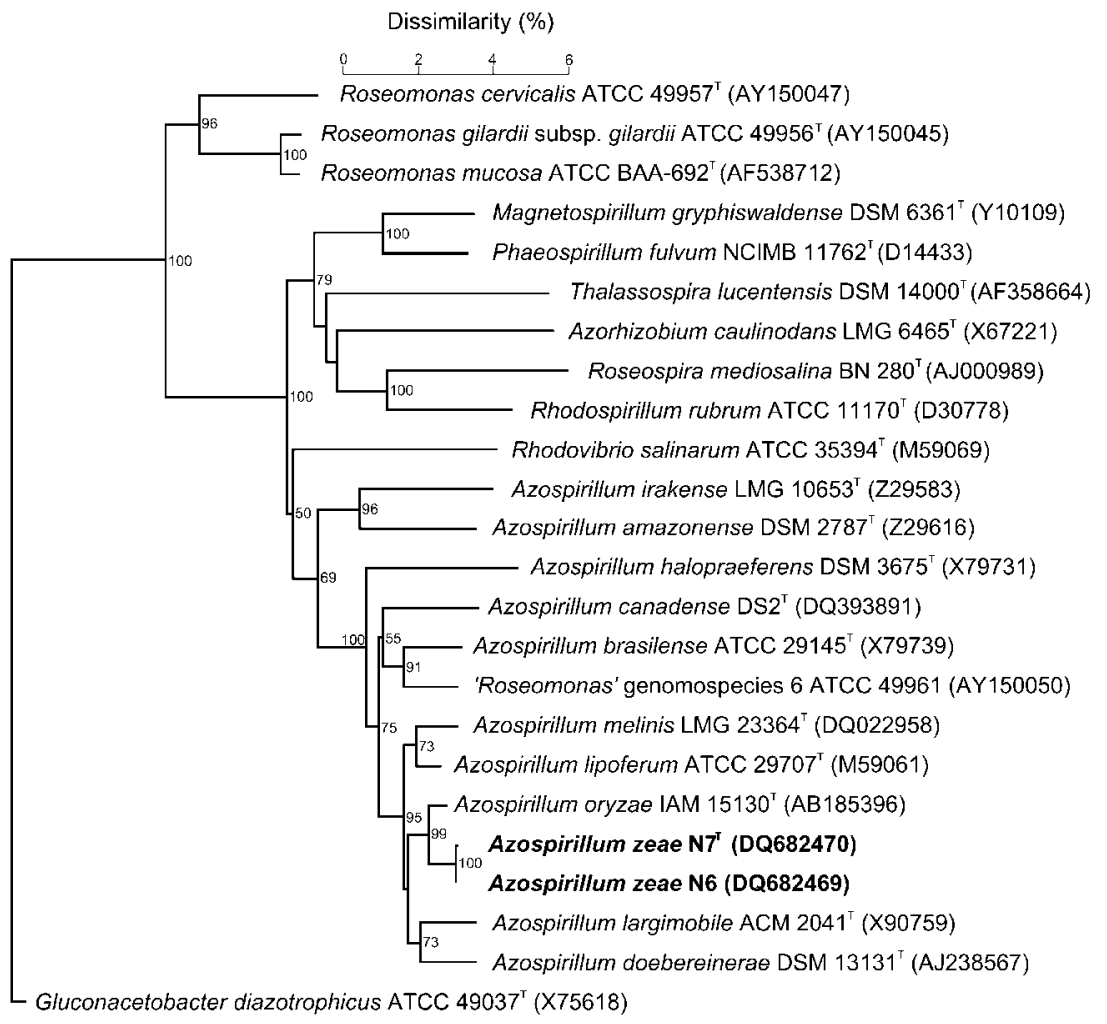

Fig. 2. Phylogenetic tree based on $16 \mathrm{~S}$ rRNA gene sequences constructed by the neighbour-joining method showing the close relationship between strains $\mathrm{N}^{\top}$ and $\mathrm{N} 6$ and the nearest relatives of the genus Azospirillum. Numbers at nodes indicate percentages of occurrence in 1000 bootstrapped trees; only values greater than $50 \%$ are shown. 
pairwise, calculated by using an open gap penalty of $100 \%$ and a unit gap penalty of $0 \%$. A similarity matrix was created by homology calculation with a gap penalty of $0 \%$ and after discarding unknown bases. The resulting tree, based on a comparison of 1482 and 1488 bases of N6 and $\mathrm{N}^{\mathrm{T}}$, respectively, was constructed using the neighbourjoining method. Bootstrap analysis was performed using the same software package to test the statistical reliability of the topology of the neighbour-joining tree with 1000 bootstrap resamples of the data. On the basis of the distance matrix, $16 \mathrm{~S}$ rRNA gene sequence similarity values indicated that the closest relatives to strains $\mathrm{N} 6$ and $\mathrm{N}^{\mathrm{T}}$ are A. oryzae IAM $15130^{\mathrm{T}}$ (98.8 and $98.7 \%$ similarity, respectively), A. lipoferum ATCC $29707^{\mathrm{T}}$ (97.6 and $97.5 \%$ similarity, respectively), A. melinis TMCY $0552^{\mathrm{T}}$ (97.3 and $97.2 \%$ similarity, respectively), A. largimobile ACM $2041^{\mathrm{T}}$ (96.8 and $96.9 \%$ similarity, respectively) and A. doebereinerae DSM $13131^{\mathrm{T}}$ (96.7 and $96.7 \%$ similarity, respectively). The phylogenetic tree based on $16 \mathrm{~S}$ rRNA gene sequences constructed by using neighbour-joining method is shown in Fig. 2.

DNA-DNA hybridization was performed at $38.5{ }^{\circ} \mathrm{C}$ according to a modification of the method described by Ezaki et al. (1989). For isolate $\mathrm{N}^{\mathrm{T}}$, DNA-DNA hybridization results showed reassociation values of $37 \%$ with $A$. oryzae IAM $15130^{\mathrm{T}}$ and $43 \%$ with A. lipoferum ATCC $29707^{\mathrm{T}}$; isolate N6 showed $48 \%$ reassociation with $A$. oryzae IAM $15130^{\mathrm{T}}$ and $43 \%$ reassociation with $A$. lipoferum ATCC $29707^{\mathrm{T}}$. Isolates $\mathrm{N} 6$ and $\mathrm{N}^{\mathrm{T}}$ showed $98 \%$ reassociation with each other.

The chaperonin gene ( $p$ n 60$)$ was amplified from bacterial genomic DNA of isolates $\mathrm{N} 6$ and $\mathrm{N}^{\mathrm{T}}$ using universal cpn60 degenerate primers and PCR conditions described by Mehnaz et al. (2007). The DNA sequences of $\mathrm{N} 6$ and $N 7^{\mathrm{T}}$ showed 95.1 and $93.9 \%$ similarity, respectively, with the cpn60 sequence of $A$. oryzae IAM $15130^{\mathrm{T}}$ (GenBank accession no. DQ813649), 82.8 and $82.1 \%$ similarity, respectively, with that of A. lipoferum ATCC $29707^{\mathrm{T}}$ (GenBank accession no. DQ813650), and 81 and $80.7 \%$ similarity, respectively, with that of A. melinis TMCY $0552^{\mathrm{T}}$ (GenBank accession no. EF428027). Strains N6 and $N 7^{\mathrm{T}}$ showed $98.7 \%$ sequence similarity with each other.

Semi-solid M medium was used for the acetylene reduction assay, which was carried out as described by Mehnaz \& Lazarovits (2006). Veil-like subsurface pellicle formation and very high nitrogenase activity, i.e. $5.9-6.6 \mu \mathrm{mol}$ ethylene $\mathrm{h}^{-1}$ (mg protein $)^{-1}$, was observed. The nifH gene was amplified by PCR using the primer set PolF/PolR and the conditions described by Poly et al. (2001). The expected $360 \mathrm{bp}$ amplification product was observed. This PCR product was purified and sequenced. Comparison of results using BLAST (NCBI) revealed highest sequence similarities with the nifH gene of A. oryzae IAM $15130^{\mathrm{T}}$ (98.5 and $97.6 \%$, respectively, for strains $\mathrm{N} 6$ and $\mathrm{N}^{\mathrm{T}}$ ), $A$. lipoferum ATCC $29707^{\mathrm{T}}$ (96.6 and $96.3 \%$, respectively) and A. brasilense sp. $7^{\mathrm{T}}$ (93.5 and $93.3 \%$, respectively).

\section{Description of Azospirillum zeae sp. nov.}

Azospirillum zeae [L. gen. n. zeae of spelt, of Zea mays, referring to its isolation from rhizosphere soil of corn ( $Z e a$ mays)].

Cells are rods, $0.9-1.5 \times 1.9-6.8 \mu \mathrm{m}$ in size, Gram-negative, motile via a single polar flagellum. Pink colonies form after 48-72 h, which become wrinkled and dried with time. Growth occurs on $\mathrm{M}$ medium at $20-41{ }^{\circ} \mathrm{C}, \mathrm{pH} 5-7$ and in $0.5-1.0 \% \mathrm{NaCl}$. Optimum growth occurs at $30{ }^{\circ} \mathrm{C}$ and $\mathrm{pH}$ 5-7. Positive for nitrogen fixation and IAA production; negative for phosphate solubilization. L-Arabinose, D-fructose, L-fucose, D-galactose, D-glucose, D-mannitol, D-sorbitol, D-psicose, D- and L-alanine, L-asparagine, Lleucine, L-ornithine, L-phenylalanine, L-proline, L-serine, L-threonine, acetic acid, $\alpha$-aminobutyric acid, L-hydroxybutyric acid, L-aspartic acid, bromosuccinic acid, formic acid, $\alpha$ - and $\beta$-hydroxybutyric acid, D-galacturonic acid, Lglutamic acid, $\alpha$-ketoglutaric acid, DL-lactic acid, malic acid, phenylacetic acid, propionic acid, D-saccharic acid, succinic acid, urocanic acid, $N$-acetyl-D-glucosamine, potassium gluconate, Tweens 80 and 40 , pyruvic acid methyl ester, succinic acid monomethyl ester, p-hydroxyphenylacetic acid, 2-aminoethanol, 2,3-butanediol, glucuronamide, L-alaninamide and glycerol can be used as unique carbon sources. D-Arabitol, D-cellobiose, myoinositol, D-lactose, D-mannose, D-melibiose, D-raffinose, L-rhamnose, trehalose, gentiobiose, sucrose, maltose, xylitol, succinamic acid, quinic acid, malonic acid, D-glucuronic acid, cis-aconitic acid, citric acid, L-erythritol, D-gluconic acid, $\alpha$-ketobutyric acid, L-histidine, D-serine, trisodium citrate, capric acid and adipic acid are not utilized. Positive for catalase, oxidase, urease, nitrate reduction, aesculin hydrolysis and $\beta$-galactosidase. Negative for indole production, arginine dihydrolase and gelatin hydrolysis. Variable response for acetoin production. Biotin is not required for growth. Major cellular fatty acids are $18: 1 \omega 7 c, 18: 12-\mathrm{OH}$ and $16: 0$. The predominant quinone system is ubiquinone (Q-10). The DNA G+C content of the type strain is $67.6 \mathrm{~mol} \%$.

The type strain, $\mathrm{N}^{\mathrm{T}}\left(=\mathrm{NCCB} 100147^{\mathrm{T}}=\mathrm{LMG} 23989^{\mathrm{T}}\right)$, was isolated from rhizosphere soil of corn (Zea mays) from London, Ontario, Canada.

\section{Acknowledgements}

We are thankful to Denise Chabot and the EM unit, Agriculture and Agri-Food Canada, Ottawa, for electron microscopy and Dr Janet Hill, National Research Council Plant Biotechnology Institute, Saskatoon, Saskatchewan, Canada, for chaperonin sequence analysis. This work was supported by grants from Commercial Alcohols Inc., Brampton, Ontario and Agriculture and Agri-Food Canada MII Initiative.

\section{References}

Ben Dekhil, S., Cahill, M., Stackebrandt, E. \& Sly, L. I. (1997). Transfer of Conglomeromonas largomobilis subsp. largomobilis to the 
genus Azospirillum as Azospirillum largomobile comb. nov., and elevation of Conglomeromonas largomobilis subsp. parooensis to the new type species of Conglomeromonas, Conglomeromonas parooensis sp. nov. Syst Appl Microbiol 20, 72-77.

Eckert, B., Weber, O. B., Kirchhof, G., Halbritter, A., Stoffels, M. \& Hartmann, A. (2001). Azospirillum doebereinerae sp. nov., a nitrogenfixing bacterium associated with the $\mathrm{C}_{4}$-grass Miscanthus. Int J Syst Evol Microbiol 51, 17-26.

Ezaki, T., Hashimoto, Y. \& Yabuuchi, E. (1989). Fluorometric deoxyribonucleic acid-deoxyribonucleic acid hybridization in microdilution wells as an alternative to membrane filter hybridization in which radioisotopes are used to determine genetic relatedness among bacterial strains. Int J Syst Bacteriol 39, 224-229.

Khammas, K. M., Ageron, E., Grimont, P. A. D. \& Kaiser, P. (1989). Azospirillum irakense sp. nov., a nitrogen-fixing bacterium associated with rice roots and rhizosphere soil. Res Microbiol 140, 679-693.

Magalhães, F. M., Baldani, J. I., Souto, S. M., Kuykendall, J. R. \& Döbereiner, J. (1983). A new acid-tolerant Azospirillum species. An Acad Bras Cienc 55, 417-430.

Mehnaz, S. \& Lazarovits, G. (2006). Inoculation effects of Pseudomonas putida, Gluconacetobacter azotocaptans and Azospirillum lipoferum on corn plant growth under green house conditions. Microb Ecol 51, 326-335.

Mehnaz, S., Mirza, M. S., Huarat, J., Bally, R., Normand, P. \& Malik, K. A. (2001). Isolation and $16 \mathrm{~S}$ rRNA sequence analysis of the beneficial bacteria from the rhizosphere of rice. Can J Microbiol 47, 110-117.

Mehnaz, S., Weselowski, B. \& Lazarovits, G. (2007). Azospirillum canadense sp. nov., a nitrogen-fixing bacterium isolated from corn rhizosphere. Int J Syst Evol Microbiol 57, 620-624.
Mesbah, M., Premachandran, U. \& Whitman, W. B. (1989). Precise measurement of the $\mathrm{G}+\mathrm{C}$ content of deoxyribonucleic acid by highperformance liquid chromatography. Int J Syst Bacteriol 39, 159-167.

Nautiyal, C. S. (1999). An efficient microbiological growth medium for screening phosphate solubilizing microorganisms. FEMS Microbiol Lett 170, 265-270.

Normand, P. (1995). Utilisation des séquences $16 \mathrm{~S}$ pour le positionnement phylétique d'un organisme inconnu. Oceanis 21, 31-56.

Paisley, R. (1996). MIS Whole Cell Fatty Acid Analysis by Gas Chromatography Training Manual. Newark, DE: MIDI.

Peng, G., Wang, H., Zhang, G., Hou, W., Liu, Y., Wang, E. T. \& Tan, Z. (2006). Azospirillum melinis sp. nov., a group of diazotrophs isolated from tropical molasses grass. Int J Syst Evol Microbiol 56, 1263-1271.

Poly, F., Monrozier, L. J. \& Bally, R. (2001). Improvement in the RFLP procedure for studying the diversity of nifH genes in communities of nitrogen fixers in soil. Res Microbiol 152, 95-103.

Reinhold, B., Hurek, T., Fendrik, I., Pot, B., Gillis, M., Kersters, K., Thielemans, S. \& De Ley, J. (1987). Azospirillum halopraeferens sp. nov., a nitrogen fixing organism associated with roots of kallar grass (Leptochloa fusca (L.) Kunth). Int J Syst Bacteriol 37, 43-51.

Rennie, R. J. (1981). A single medium for the isolation of nitrogen fixing bacteria. Can J Microbiol 27, 8-14.

Tarrand, J. J., Kreig, N. R. \& Döbereiner, J. (1978). A taxonomic study of the Spirillum lipoferum group, with descriptions of a new genus, Azospirillum gen. nov., and two species, Azospirillum lipoferum (Beijerinck) comb. nov. and Azospirillum brasilense sp. nov. Can J Microbiol 24, 967-980.

Xie, C.-H. \& Yokota, A. (2005). Azospirillum oryzae sp. nov., a nitrogen-fixing bacterium isolated from the roots of the rice plant Oryza sativa. Int J Syst Evol Microbiol 55, 1435-1438. 